\title{
Effectiveness of BAP (6-Benzyl Amino Purine) for Buds Induction of Nutmeg (Myristica fragrans Houtt.)
}

\author{
Dedi Satriawan ${ }^{1, *}$ Steffanie Nurliana ${ }^{1}$ Tutik Pujiyanti ${ }^{2}$ \\ ${ }^{1}$ Department of Biology, Faculty of Mathematics and Natural Sciences, University of Bengkulu, KandangLimun, \\ Bengkulu 38371, Indonesia \\ ${ }^{2}$ Undergraduate Student, Department of Biology, Faculty of Mathematics and Natural Sciences, University of \\ Bengkulu, KandangLimun, Bengkulu 38371, Indonesia \\ *Corresponding author: dedisatriawan1984@gmail.com
}

\begin{abstract}
This research aims to determine the most effective of BAP concentration for bud's induction of nutmeg. The nutmeg plants used are obtained from the village of TanjungAgung, Sukamerindu, Bengkulu. The research was conducted from November to December 2019, at the Biotechnology Laboratory, Department of Agronomy, Faculty of Agriculture, Bengkulu University. This study used 6 of BAP treatments and 4 replications. The BAP concentration treatments given were 0 ppm, 8 ppm, 9 ppm, 10 ppm, 11 ppm and $12 \mathrm{ppm}$. The results showed BAP concentrations of $0 \mathrm{ppm}, 8 \mathrm{ppm}$ and $12 \mathrm{ppm}$ obtained 1 plant that produced bud, at a concentration of 9 ppm and $10 \mathrm{ppm}$ obtained 2 plants that produced bud, and at a concentration of $11 \mathrm{ppm}$ there were 4 plants that produced bud.
\end{abstract}

Keywords: BAP, bud, Nutmeg

\section{INTRODUCTION}

Pala has 3 type of flower; dioecious, monoecious and polygamus. Reproduction of Pala can occur generatifly or vegetatifly. Vegetatif reproduction make problem that we can not know ratio of male and female plants. This problem be a big obstacle for big plantation [1].

Propagation via plant tissue culture (in vitro) has many excellences than others. The plantlet can spesifically and healthier. Duration for massive propagation is shorter than others. The plantlets are identically with parental. This propagation can do whenever does not depend on season, geographical condition etc. [2].

One of success key for this propagation (especially bud induction) is cytokinin. Benzyl amino purine (BAP) is great cytokinin for induce cell propagation. BAP was recently used for bud's induction via in vitro. Pre-research was done for 0,1 , 5 and $10 \mathrm{ppm}$ of BAP. The best result is $10 \mathrm{ppm}$
BAP. So, this research uses 8, 9, 10, 11 and $12 \mathrm{ppm}$ of BAP.

\section{MATERIALS AND METHODS}

This study used a completely randomized design (CRD) consisting of six treatments; $0,8,9,10,11$ and $12 \mathrm{ppm}$. Each treatment was carried out in 4 (four) replications.

Data on the percentage of living explants, the percentage of explants forming shoots and the average number of shoots were statistically analyzed for variance using analysis of variance ( $\mathrm{F}$ test of 5\% level). If there is a significant difference (Fcount> FTabel), then proceed with the Duncan Multiple Range average difference test at the 5\% level [3]. Data on the mean time to emergence of shoots were analyzed descriptively.

\section{RESULT AND DISCUSSION}

The percentage of live explants in each treatment was $100 \%$. The viability of the explants depends on 


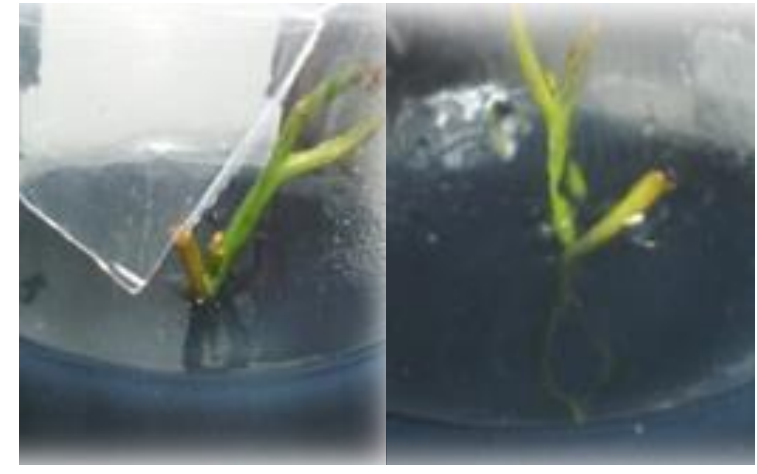

Figure 1. Nutmeg buds at $0 \mathrm{ppm}$ of BAP

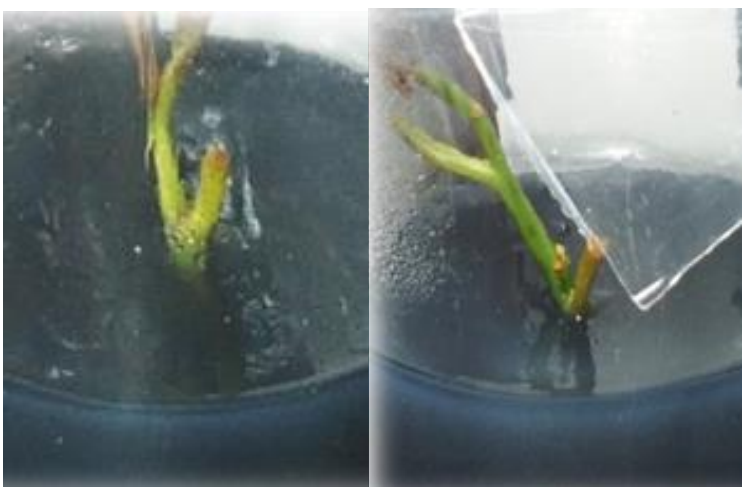

Figure 3. Nutmeg buds at 9 ppm of BAP

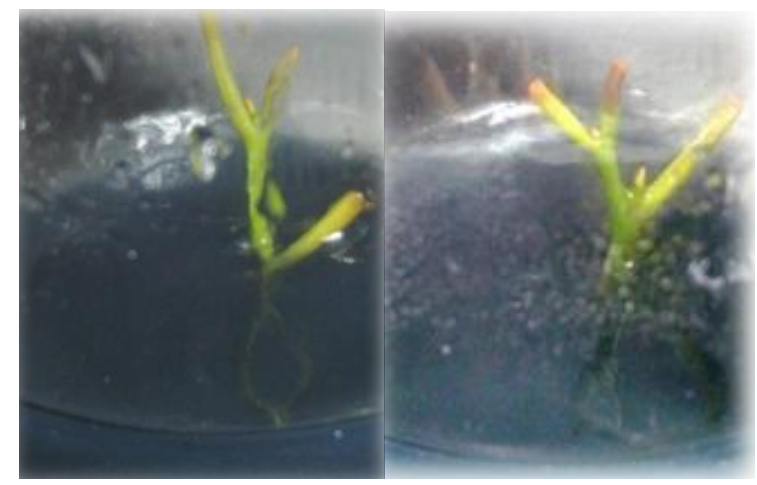

Figure 5. Nutmeg buds at $11 \mathrm{ppm}$ BAP treatment

the availability of nutrients and vitamins. Nutrients and vitamins must be available in sufficient quantities in the media used. Triaminingsih [4] stated that success in tissue culture techniques is largely determined by the culture media used. Another factor that supports live explants in this study is that the explants used are derived from the apical shoot meristem tissue whose cells are still actively propagating. In accordance with Sari \& Ibrahim's [5] statement that explants are one of the important factors that determine the success of plant tissue culture, the explants used still meristematically.

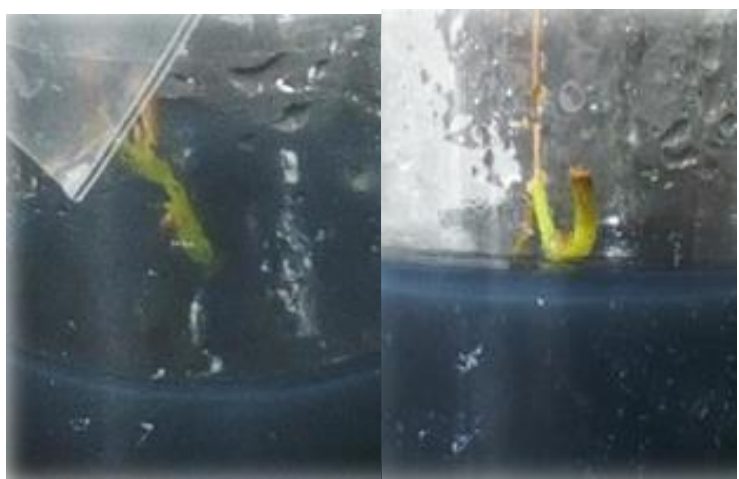

Figure 2. Nutmeg buds at 8 ppm of BAP

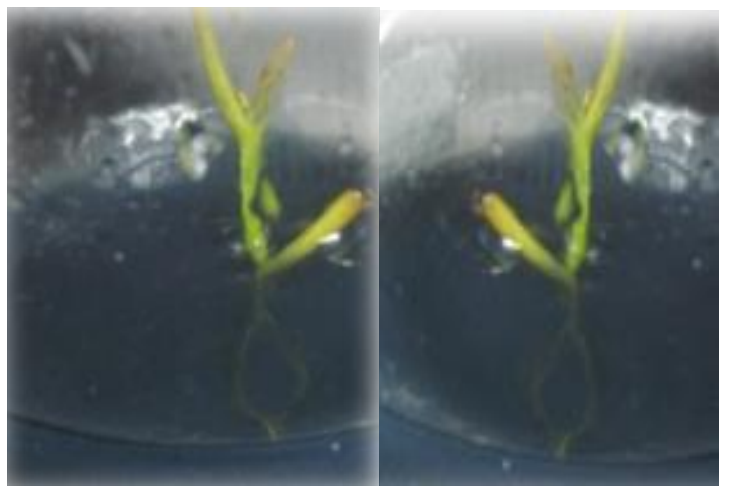

Figure 4. Nutmeg buds at $10 \mathrm{ppm}$ BAP treatment

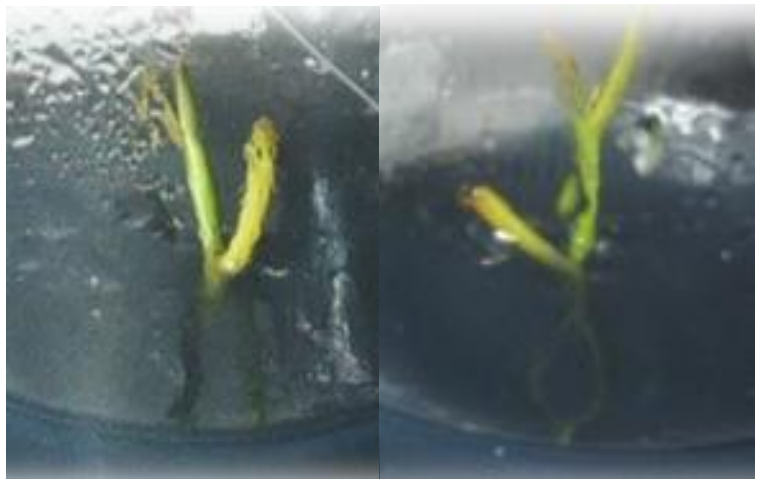

Figure 6. Nutmeg buds at $11 \mathrm{ppm}$ BAP treatment

In Table 1, it can be seen that there is a difference in the percentage of explants forming shoots of the nutmeg plant (Myristica fragrans Hout.). The addition of BAP at a concentration of $8 \mathrm{ppm}$ and 12 ppm was not effective in increasing the percentage of explants forming axillary shoots (see Figure 2 and Figure 6). At a concentration of $9 \mathrm{ppm}$ and $10 \mathrm{ppm}$; addition of BAP was quite effective in stimulating the growth of nutmeg shoots (see Figure 3 and Figure 4). The most effective concentration in inducing buds' growth was $11 \mathrm{ppm}, 100 \%$ of the explants formed buds (see Figure 5). 
Table 1. Percentage of explants that form buds

\begin{tabular}{cc}
\hline $\begin{array}{c}\text { BAP dosage } \\
(\mathbf{p p m})\end{array}$ & $\begin{array}{c}\text { Percentage of explants that } \\
\text { form buds }\end{array}$ \\
\hline 0 & $25 \mathrm{a}$ \\
8 & $25 \mathrm{a}$ \\
9 & $50 \mathrm{a}$ \\
10 & $50 \mathrm{a}$ \\
11 & $100 \mathrm{~b}$ \\
12 & $25 \mathrm{a}$
\end{tabular}

$*$ Numbers in different letters mean significantly different at the $5 \%$ level.

Table 2. Average of Buds

\begin{tabular}{cc}
\hline $\begin{array}{c}\text { BAP dosage } \\
(\mathbf{p p m})\end{array}$ & Average of Buds \\
\hline 0 & $0,25 \pm 0.125 \mathrm{a}$ \\
8 & $0,25 \pm 0.125 \mathrm{a}$ \\
9 & $0,5 \pm 0.250 \mathrm{a}$ \\
10 & $0,5 \pm 0.250 \mathrm{a}$ \\
11 & $1,5 \pm 0.750 \mathrm{~b}$ \\
12 & $0,25 \pm 0.125 \mathrm{a}$ \\
\hline
\end{tabular}

*Numbers in different letters mean significantly different at the $5 \%$ level.

BAP has the ability to support the growth of axillary shoots in plants. According to Noggle and Fritz [6], BAP is the most active cytokinin. Hendaryono and Wijayani [7] stated that the determination of Plants Growth Regulator (PGR) used must be precise, not more or less. Incorrect calculations can be fatal to the tissue growth of the explants. PGR at a dose that is too high can inhibit growth while a dose that is too low does not have the desired effect.

In Table 2, it can be seen that there is a difference in the average number of buds on explants of nutmeg (Myristica fragrans Hout.). At a BAP concentration of $8 \mathrm{ppm}$ and $12 \mathrm{ppm}$, the addition of BAP was not effective in increasing the number of buds. The addition of BAP at a concentration of $9 \mathrm{ppm}$ and 10 ppm was quite effective in increasing the number of axillary buds, but had no significant difference with the concentrations of $0 \mathrm{ppm}, 8 \mathrm{ppm}$ and $12 \mathrm{ppm}$. The most effective concentration was $11 \mathrm{ppm}$ with an average number of buds $600 \%$ more effective.

According to Wattimena et al [8] and Dixon and Gonzales [9], BAP used in plant tissue culture with the right concentration will encourage bud's proliferation in explants. BAP is more frequently used than kinetin to induce rapid buds' induction.
Table 3. The time range for the appearing of the first bud (days after planting)

\begin{tabular}{ll}
\hline $\begin{array}{l}\text { BAP dosage } \\
\text { (ppm) }\end{array}$ & $\begin{array}{l}\text { The time range for the } \\
\text { appearing } \\
\text { of the first bud (days after } \\
\text { planting) }\end{array}$ \\
\hline $0 \mathrm{ppm}$ & $8-15$ \\
$8 \mathrm{ppm}$ & $9-14$ \\
$9 \mathrm{ppm}$ & $8-12$ \\
$10 \mathrm{ppm}$ & $9-17$ \\
$11 \mathrm{ppm}$ & $7-10$ \\
$12 \mathrm{ppm}$ & $8-18$ \\
\hline
\end{tabular}

In Table 3, it can be seen that there are differences in the time range for the appearing of the first bud in each treatment. Overall, the fastest time for the appearing of the first bud was 7 days after planting and the longest was 18 days after planting. Endogenous PGR is in the form of auxin which causes inhibition of axillary bud growth. The auxin hormone stimulates apical dominance (causing obstruction of axillary bud growth). BAP suppresses the dominance of apical bud (encourages the growth of axillary buds).

\section{CONCLUSION}

Based on the research that has been done, it can be concluded that the concentration of BAP is effective at a concentration of $9 \mathrm{ppm}, 10 \mathrm{ppm}$ and 11 $\mathrm{ppm}$. The concentration of BAP was most effective in inducing buds of Myristica fragrans Houtt. in vitro it was $11 \mathrm{ppm}$ with $100 \%$ explants forming axillary shoots, the average number of shoots was 1.5 buds/explant and the time for first bu appeared was the fastest (7 days).

\section{REFERENCES}

[1] Arrijani, REVIEW : Biology and Conservation of Genus Myristica in Indonesia, Biodiversitas, 6(2) (2015) 147-151. [In Bahasa Indonesia]

[2] E. Hambali, A. Suryani, Dadang, et al., Jarak Pagar: Tanaman Penghasil Biodiesel, Penebar Swadaya, Jakarta, 2006. [In Bahasa Indonesia]

[3] K.A. Gomez, A.A. Gomez, Prosedur statistik untuk penelitian pertanian, edisi kedua, translate by: S. Endang, J.S. Baharsjah, Universitas Indonesia Press, Jakarta, 1995. [In Bahasa Indonesia]

[4] R. Triatminingsih, Karsinah, H. Subakti, I. Fitrianingsih, Kultur in vitro Biji Duku. Balai Penelitian Tanaman Holtikultura Solok, Jurnal 
Holtikultura 13(2) (2003) 77-81. [In Bahasa Indonesia]

[5] M. Sari, D. Ibrahim, Faktor penentu keberhasilan perbanyakan kopi (Coffea sp.) melalui embriogenesis somatik, 2015, 127-136. [In Bahasa Indonesia]

[6] Noggle, G. R. dan G. J. Fritz. 1983. Introductory Plant Physiology: Second Edition. Prentince-Hall, Inc. New Jersey.

[7] D.P.S. Hendaryono, A. Wijayani, Teknik Kultur Jaringan, Kanisius, Yogyakarta, 1994. [In Bahasa Indonesia]

[8] G.A. Wattimena, L.W. Gunawan, N.A. Mattjik, E. Sjamsudin, M.A. Wiendi, A. Ernawati, Bioteknologi Tanaman. Departemen Pendidikan dan Kebudayaan Direktorat Jendral Pendidikan Tinggi Pusat Antar Universitas (PAU) Bioteknologi, Institut Pertanian Bogor, Bogor, 1991. [In Bahasa Indonesia]

[9] R.A. Dixon, R.A. Gonzales, Plant cell culture a pratical approach, second edition, OIRL Press at Oxford University Press, Oxford, 1994. 